Journal of Business and Management Studies (JBMS)

ISSN: $2709-0876$

DOI: 10.32996/jbms

Journal Homepage: www.al-kindipublisher.com/index.php/jbms

\title{
Effect of Promotional Mix on the Marketing of Insurance Services
}

\author{
Joseph A. Anyadighibe 1 (D) Aniebiet Etuk ${ }^{2}$ (D) James, Edim Eka ${ }^{3} 8(D)$, and Inyang, Rose Stephen ${ }^{4}(D)$ \\ ${ }^{1}$ Lecturer I, Department of Marketing, University of Calabar, Nigeria \\ ${ }^{2}$ Senior Lecturer, Department of Marketing, Akwa Ibom State University, Nigeria \\ ${ }^{3} \mathrm{PhD}$ Student, Department of Marketing, University of Calabar, Nigeria \\ ${ }^{4} \mathrm{PhD}$ Student, Department of Marketing, University of Calabar, Nigeria
}

$\triangle$ Corresponding Author: James, Edim Eka, E-mail: jamesedim@gmail.com

\begin{tabular}{|c|c|}
\hline ARTICLE INFORMATION & ABSTRACT \\
\hline Received: August 01, 2021 & \multirow{7}{*}{$\begin{array}{l}\text { This study was on the effect of promotional mix on the marketing of insurance services. } \\
\text { It aimed to examine the effects of advertising, personal selling, public relations, and } \\
\text { direct marketing on the marketing of insurance services. A cross-sectional survey } \\
\text { research design was adopted. Primary data were obtained from } 182 \text { employees of four } \\
\text { (4) insurance companies using a structured questionnaire. The hypotheses developed } \\
\text { for the study were statistically tested using inferential statistics (multiple linear } \\
\text { regression) in the Statistical Package for the Social Sciences (SPSS 23). Consequently, } \\
\text { it was found that advertising, personal selling, and direct marketing had significant } \\
\text { positive effects on the marketing of insurance services, while public relations had a } \\
\text { negative and non-significant effect on the marketing of insurance services. Therefore, } \\
\text { the study concluded that the marketing of insurance services could greatly be } \\
\text { improved through the implementation of promotional mix strategies such as } \\
\text { advertising, personal selling, and direct marketing. }\end{array}$} \\
\hline Accepted: September 28, 2021 & \\
\hline Volume: 3 & \\
\hline Issue: 2 & \\
\hline DOI: 10.32996/jbms.2021.3.2.13 & \\
\hline KEYWORDS & \\
\hline $\begin{array}{l}\text { Promotional Mix, Marketing, } \\
\text { Insurance Service, Advertising, } \\
\text { Personal Selling, Public Relations, } \\
\text { Direct Marketing. }\end{array}$ & \\
\hline
\end{tabular}

\section{Introduction}

The African insurance market has been on a steady path of growth over the past several years. The total premium's volume reported by African countries increased from 65.165 billion USD in 2018 to 68.383 billion USD in 2019, indicating a 5 percent growth increase in premium volume (Atlas Magazine, 2019). According to data published by Sigma in 2019, the African market share remained stable at 1.31 percent of the global premiums generated. South Africa was by far the leading country with 48.269 billion USD in premiums; that is 70.59 percent of the whole continent's premium income. Nigeria emerged as the fifth leading African country with 1.220 billion USD in premiums and a market share of 1.78 percent of the African continent's premium income (Atlas Magazine, 2019). A report by Agusto \& Co. (2019) maintains that for the 2019 financial year, the Nigerian insurance industry generated a gross premium income (GPI) of 471 billion, approximately 12 percent higher than the preceding year's GPI. The factors causing such improvements included supportive regulatory requirements such as bancassurance, a relatively relieved economy, and the implementation of robust infrastructural projects. Going forward, experts have predicted that the Nigerian insurance sector is expected to witness considerable growth in the medium to long term, despite an interruption in 2020 due to the COVID-19 pandemic (Benson, 2020). In specific terms, players in the smaller life insurance segment of the market are expected to grow their collective premiums by 4.8 percent to N179.81 billion in 2020. This represents a digressive projection, given the country's debilitated economy. However, the life insurance component of the insurance market is anticipated to attract higher premiums of up to N207.96 billion by 2024. Similarly, the non-life insurance component of the insurance market is projected to attract increased premiums by up to $\mathrm{N} 248.85$ billion in 2020. Benson (2020) further projects that the non-life component of the market will attract premiums at the value of N321.53 billion in 2024.

The Nigerian insurance industry has been able to attain a significant amount of growth in the past several years and is bound to reach an even higher level of growth in the future, in large part, due to the implementation of effective marketing strategies such as marketing promotion by players in the industry (Enitilo, Ajayi \& Famuagun, 2017; Idris, Asokere, Ajemunigbohun, Oreshile \&

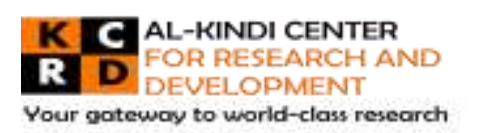

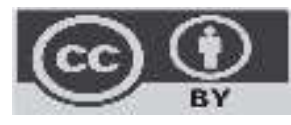

Published by Al-Kindi Center for Research and Development. Copyright (c) the author(s). This open access article is distributed under a Creative Commons Attribution (CC-BY) 4.0 license 
Olutade, 2018). Marketing promotion is the process whereby organizations communicate with potential or existing customers in order to inform, enlighten, persuade, influence, and convince them to patronize the organization's products and services (Fitchner, 2016). It is a coordinated process through which persuasive, enticing, informative, and enlightening information about an organization, its products, and services is conveyed to the target audience (customers) in order to gain the attention, interest, desire, and positive action of customers (Jefferson, 2013). Existing studies have shown that the application of a promotional mix strategy to the marketing of insurance services has resulted in the improvement of the marketing performance of insurance companies (Enitilo, Ajayi \& Famuagun, 2017; Idris et al., 2018).

Although the Nigerian insurance industry has recorded great rates of growth in the past several years, its future growth prospects are potentially hampered by certain challenges, including a slow rate of insurance service penetration among Nigerian consumers, low consumer income, low consumer knowledge about the insurance industry, negative attitude to insurance service by most religious Nigerians, and unfavorable government regulatory policies (such as high capital requirements imposed on insurance companies by the National Insurance Commission) (Idris, 2020). The marketing of insurance services in Nigeria is also inhibited by factors such as inherent difficulty in selling insurance services to Africans (Kinoti, Nkari \& Kathuni, 2019); Nigerians' general lack of enthusiasm for insurance (Benson, 2020); lack of awareness among most urban and especially rural Nigerians about the availability and benefits of insurance services (Benson, 2020); and high illiteracy among most Nigerians in rural areas and even in urban areas (Enitilo, Ajayi \& Famuagun, 2017). In an attempt to mitigate the challenges of marketing insurance services in Nigeria, insurance companies have designed and implemented various promotional mix strategies, such as advertising, sales promotion, personal selling, public relations, and direct marketing with the objective of changing Nigerians' attitudes towards insurance services; and encouraging the patronage of insurance packages. The problem of the study was therefore summarized in the following question: How effective are the promotional mix strategies of insurance companies at enhancing the marketing of insurance services? Consequently, the study was therefore carried out to verify the extent to which promotional mix strategies such as advertising (outdoor advertising, print advertising, radio advertising); personal selling (order taker, order getter, tele-seller); public relations (press release, publication, event) and direct marketing (email, social media, website) have influenced the marketing of insurance service packages.

\section{Literature Review}

\subsection{Theoretical Framework}

The study is anchored in the framework provided by the rapid response model of marketing communication propounded by Logan and Edwards (2004). The rapid response model of marketing communication was propounded by Logan and Edwards (2004), to illustrate how marketing communication can effectively be used to gain rapid positive responses from target audiences. The basic premise of the theory is that marketing communication enables firms to effectively gain favorable rapid responses from their target audience by triggering a cognitive reaction in the target audience if and only if the integrated marketing communication approach is adopted. Integrated marketing communication (IMC) is the consolidation and utilization of all the promotional tools at a firm's disposal to deliver a consistent, clear, and impactful message capable of generating desired responses from the target audience. Under the integrated marketing communication orientation, a consistent, uniform, and comprehensive promotional message and content is delivered through all the promotional tools at a firm's disposal. An integrated approach to marketing communication should be adopted using all promotional tools at a firm's disposal to generate favorable responses from the target audience. A consistent, persuasive, convincing, and attractive message and content should be deployed across all promotional platforms (such as advertising, personal selling, sales promotion, public relations, publicity, word of mouth, and direct marketing: internet marketing, social media marketing, and email marketing). The promotional message must describe the features, advantages, and benefits (FAB) as well as the unique selling propositions (USP) of the product/service promoted in order to effectively gain positive rapid responses from the target audience. Marketing communication (promotion) becomes more effective when all promotional tools of a firm are consolidated, synchronized, and utilized to deliver a consistent message capable of triggering a positive cognitive reaction in the minds of the target audience. Marketing communication triggers a positive cognitive reaction grabbing the attention, interest, liking, preference, desire, purchase, and willingness to repurchase and recommend the firm's products/services. However, for marketing communication to effectively trigger a positive cognitive reaction in the minds of the target audience that translates into positive rapid responses from the target audience, an integrated approach must be adopted. The relevance of the rapid response model of marketing communication to this study is that it suggests that marketing communication could enable insurance companies to effectively gain favourable rapid responses from consumers by triggering a cognitive reaction in their minds. The theory affirms that marketing communication of insurance companies can effectively be used to gain positive rapid responses from target audiences if the integrated marketing communication approach is adopted. Under this orientation, the theory emphasizes that insurance companies can generate desired responses from their target audiences and improve their marketing performance by consolidating and utilizing all the promotional tools at their disposal (such as advertising, personal selling, sales promotion, public relations, publicity, word of mouth, and direct marketing) to deliver consistent, clear, and impactful messages to insurance consumers. Similarly, the theory maintains that the promotional messages of insurance companies must 
describe the features, advantages, and benefits (FAB) as well as the unique selling propositions (USP) of their insurance services promoted so as to effectively gain positive rapid responses from the target audience.

\subsection{Conceptual Framework}

This study examined the effect of the promotional mix on the marketing of insurance services. To accomplish this objective, the independent variable "promotional mix" was decomposed into specific indicators that enabled the effective measurement of the effect of the independent variable on the dependent variable (marketing of insurance services). These indicators comprised: advertising, personal selling, public relations, and direct marketing. Advertising is a non-personal and paid-for means for insurance companies to present and promote their services to consumers through a set of media or channels of communication. In personal selling, salespersons of insurance companies directly and personally make contact and interact with potential or actual consumers of insurance services to influence and persuade them to buy or re-buy an insurance policy or programme. Public relations is the planned and sustained effort by insurance companies to gain consumers' goodwill and maintain a positive image in the eyes and minds of the public. Finally, direct marketing is a system of marketing deployed by insurance companies that interact with, and delivers their products, services, and communications to consumers directly, without intermediaries, using information and communication technologies (ICT) such as email, social media, and the internet. Informed by an in-depth review of existing studies, this study assumed that through these specific parameters, the promotional mix has some effects on the marketing of insurance services. The hypothesized relationship between the independent variable (promotional mix) and the dependent variable (marketing of insurance services) is presented on the conceptual model developed for the study.

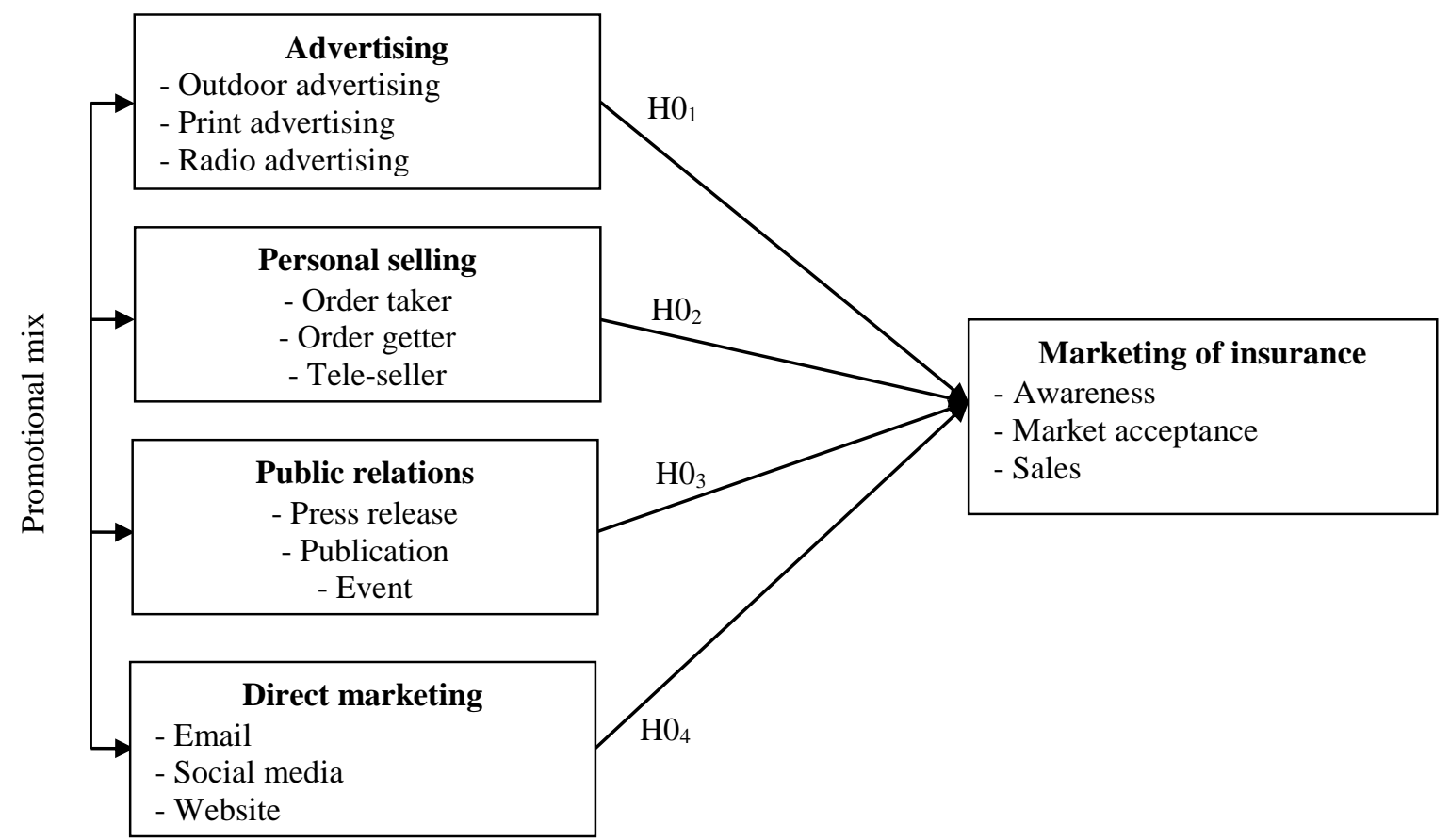

Fig. 1: Conceptual Framework of the Study

Source: Adapted from Enitilo, Ajayi, and Famuagun (2017); and Idris et al. (2018)

\subsection{Promotional Mix}

A promotional mix is a collection of various promotional tools coordinated and utilized by business organizations to maximize the performance of their promotional campaigns. The marketer's task is to find the right promotion mix for a particular brand (Ericsson, 2020). It is the coordination of a variety of promotional methods by marketers to stimulate and encourage customers to patronize their offerings (Maxwell, 2017). It is the specific combination of promotional tools, channels, and processes in order to effectively promote the goods, services, and brand of a business organization. Having defined what the promotional mix is, it is essential to discuss what is meant by the term 'promotion' in marketing. According to Dominic and Tancredi (2012), promotion is the process whereby organizations reach out to their target customers through a number of media in order to inform, educate, remind, and apprise them of their product mix and operations in the hopes of influencing positive responses from customers. It extends beyond a company's efforts at increasing customer patronage and encompasses the broader objective of influencing consumers to react in a positive manner towards companies and their offerings. According to Wade, Williams, and Bradley (2019), promotion is a process through which organizations communicate with their target audiences in order to inform, direct, remind, update, convince, persuade and encourage customers to adopt, purchase, and consume their offerings by executing innovative campaigns using 
personal selling, direct marketing, advertising, sales promotion, public relations, and word-of-mouth communication. In the view of Wayne, Purcell, and Robert (2016), promotion is executed using a number of tools, known as promotional tools, and they basically include: advertising, personal selling, public relations, publicity, sales promotion, direct marketing, and word of mouth. These promotional tools are deliberately harmonized, consolidated, and deployed to persuasively interact with both actual and potential consumers to enhance sales, and marketing performance. Furthermore, Ebitu (2012) asserts that promotion coordinates interpret, and delivers an organization's messages in a deliberate and systematic manner to the consumer to create awareness, persuade, remind and lead the consumer to appreciate or accept to buy the company's offerings. It is a means of influencing and changing consumers' attitudes and actions towards a product. The author further emphasizes that it is a purposeful, deliberate, or planned communication strategy. In the views of Shao, Shinzo, and Kyutomo (2019), a promotional mix could be regarded as an intermix of promotional elements by business organizations or entities used to deliver promotional campaigns capable of realizing their promotional objectives. It is a key component of the marketing mix of business organizations, including insurance companies. For effective results to be achieved, it is imperative for marketers to identify the right combination of promotional elements uniquely capable of effectively promoting their specific offerings because various product or service categories require distinct promotional mix strategies. Generally, however, the activities identified as elements of the promotional mix vary, but typically include advertising, personal selling, sales promotion, public relations, and direct marketing (Shao, Shinzo \& Kyutomo, 2019).

\subsection{Marketing of Insurance Services}

Insurance services are policies offered by insurance companies to the public for attention, subscription, and consumption. These include contracts meant to protect property, such as houses, furnishings, and vehicles against loss; reimbursement of health care costs; and to provide death benefits to designated beneficiaries for life insurance policyholders (Gera, Mittal, Batra \& Prasad, 2017). The marketing of insurance services is the conception, pricing, promotion, distribution, and sale of insurance policies or services to consumers in order to satisfy their needs for safety from unforeseen, unpredictable, and possible disasters (Ratnakaram, Chakravaram, Vihari \& Rao, 2020). It encompasses the formulation, implementation, and execution of marketing strategies (including promotional mix) for the purpose of influencing and convincing consumers to subscribe to insurance policies or services. Insurance services, like every other service, are marketed through a variety of marketing strategies; however, given the unsought and technical nature of insurance services, companies have developed specialized marketing strategies uniquely capable of facilitating the marketing of insurance services (Mathur, 2020). These specialized marketing strategies include:

(a) Advertising: A key marketing strategy designed and applied in the marketing of insurance services is advertising (Gollust, Wilcock, Fowler, Barry, Niederdeppe, Baum \& Karaca-Mandic, 2018), which is the non-personal and paid-for promotion of products, services, and/or ideas through the mass media by an identified source (Shao, Shinzo \& Kyutomo, 2019). Using specialized advertising media such as television, billboards, magazines/newspapers, lamp posts, etcetera, insurance companies have been able to target their services and promotional contents at groups of actual and potential consumers in order to enlighten them on the imperatives and essentials of coverage by an insurance policy with the objective of influencing them (through facts, figures, humor or other appeals) to adopt a policy (Abeid, 2019).

(b) Personal selling: Another essential marketing strategy used to promote the marketing of insurance services is personal selling (Olumoko, Abass \& Dansu, 2017), which is the direct contact between insurance company sales representatives and consumers with the objective of informing, educating, influencing and persuading consumers to develop a positive attitude towards insurance services and adopt an insurance policy (Idris, Asokere, Ajemunigbohun, Oreshile \& Olutade, 2018). Due to the intangible and unsought nature of insurance services in most traditional societies, salespersons are recruited by insurance companies to enlighten, convince, persuade and influence people to subscribe to insurance policies. The personal selling strategy is very effective at enhancing marketing performance when appropriately applied to the marketing of insurance services (Nyarko, 2015).

(c) Sales promotion: According to Kinoti, Nkari, and Kathuni (2019), sales promotion is an effective marketing strategy adopted by insurance companies to advance the marketing of insurance services. Due to consumers' general negative attitude towards insurance in most societies, insurance companies had long sought a marketing strategy that would enable them effectively attract and entice consumers to adopt insurance policies; and one of such marketing strategies implemented is sales promotion (Novi, 2020). Using sales promotional tools such as discounts, price-offs, premium, exhibitions, among others, insurance companies have been able to sufficiently incentivize consumers to patronize insurance services. However, the effectiveness of sales promotion strategy in the marketing of insurance services is limited and not guaranteed to be successful in all circumstances due to the fact that consumers of insurance services are rational, well-informed, and driven by facts, figures and logic so they always require a rational, well-thought-out reason for adopting an insurance policy rather than attracted by incentives (Prymostka, 2018).

(d) Direct marketing and relationship marketing: In the views of Enitilo, Ajayi, and Famuagun (2017) and Isimoya and Olaniyan (2020), direct marketing and relationship marketing are important marketing strategies adopted by insurance companies to advance the marketing of their policies or services. Given the rapid globalization of the world and the modernization of communication technologies, insurance companies have crafted digitized mechanisms or channels for communicating with 
consumers in order to promote their services. These channels include social media, electronic mail (E-Mail), telephones, websites, blogs, and mobile application software. Through these direct marketing tools, insurance companies have been able to directly target, interact and communicate with potential and actual consumers in order to persuade and obtain patronage (Isimoya \& Olaniyan, 2020). Also, given that one of the obstacles to the marketing of insurance services is the lack of trust between consumers and insurance companies, insurance companies have adopted the relationship marketing strategy in order to establish, nurture and sustain healthy and value-laden relationships with consumers in an attempt to build valuable trust among consumers recognizing that it catalyzes customers' patronage of insurance companies (Minta, 2018).

(e) Public relations/publicity: Perhaps one of the most useful marketing strategies adopted by insurance companies is public relations (Idris et al., 2018). Recognizing the imperatives of maintaining a good corporate image and public goodwill, insurance companies have resorted to public relations strategies (such as press releases, conferences, seminars, corporate social responsibility, corporate philanthropy, etc) to maintain and sustain a cordial and mutually-beneficial relationship with their publics (local communities, customers, employees, media organizations, financial organizations, shareholders and governments) (Okpulor, 2017). The application of public relations strategies in the marketing of insurance services has since resulted in improved marketing performance for insurance companies (Idris et al., 2018).

\subsection{Empirical Review}

Anyadighibe, Awara, and Esu (2014) conducted a study on "The impact of personal selling on the productivity of selected banks in Calabar Metropolis". The aim of the study was to assess the impact of personal selling on the productivity of selected banks (First Bank PIC and Stanbic IBTC) in Calabar Metropolis. The study adopted primary data from bank staff in Calabar Metropolis using an in-depth interview method. The hypotheses of the study were tested using Ordinary Least Square (OLS) method. Consequently, the findings of the study revealed that personal selling had a significant positive relationship with customer relationship, customer retention, and banks' sales volume. Therefore, it was recommended that banks should intensify their adoption of the personal selling strategy in order to improve their productivity. Aduloju, Odugbesan, and Oke (2018) conducted a study on "The effects of advertising media on sales of insurance products: A developing-country case". The study was conducted to determine the effect of advertising (radio advertising, television advertising, social media advertising, and billboard advertising) on the sales volume and public image of insurance companies in Lagos, Nigeria. Primary data were obtained from 201 staff of selected insurance companies in Lagos State using survey questionnaires. Data analysis was done using multiple linear regression. Subsequently, the findings revealed that radio advertising, television advertising, social media advertising, and billboard advertising had a significant effect on the sales volume and public image of insurance companies in Lagos. Hence, the study concluded that advertising had a significant effect on the sales of insurance products in Nigeria. Therefore, the study recommended that insurance companies in Nigeria should employ various advertising media to effectively improve the sales of their products.

Enitilo, Ajayi, and Famuagun (2017) conducted a study on the "Influence of promotional activities on consumers' patronage of insurance business in Ado Ekiti Metropolis, Nigeria". The study was designed to assess the influence of promotional activities on consumers' patronage of insurance businesses in Ado-Ekiti Metropolis, Nigeria. A research questionnaire was used to obtain primary data from 373 customers of insurance companies operating within Ado-Ekiti Metropolis. Multiple linear regression was the statistical tool used for data analysis. The findings of the study revealed that media advertising, personal selling, sales promotion, and direct marketing had a significant influence on customer patronage of insurance companies in Ado-Ekiti. Consequently, the study concluded that prospective marketing managers, insurance brokers, insurance agents, and other insurance practitioners should design and implement effective promotional activities in order to influence customer patronage. Idris et al. (2018) conducted a study on "An empirical study of the efficacy of marketing communication mix elements in selected insurance companies in Nigeria". The aim of the study was to draw attention to the importance of certain elements of marketing communication in premium income generation and the volume of insurance businesses in Nigeria's insurance industry. Telephone survey methods and structured questionnaires (electronic and traditional) were used to obtain primary data from 216 employees of 20 insurance companies in Lagos, Ibadan, Port Harcourt, and Abuja. Data analysis was done using descriptive statistical techniques (simple percentages and frequencies). The findings revealed that advertising, personal selling, public relations, and direct marketing significantly improved the marketing of insurance services in Nigeria. The study, therefore, recommended that the effective use of the various elements of marketing communication will help provide information, create more awareness, change attitude and perception, build industry's image and enhance brand loyalty.

Similarly, Kinoti, Nkari, and Kathuni (2019) examined "Promotional strategies and sales performance of insurance companies". The purpose of this study was to determine the effect of promotional activities on the sales performance of Insurance companies in Kenya. Primary data were collected from 175 branch managers, unit managers, and salespeople of insurance companies operating in Embu County, Kenya, with the aid of a structured questionnaire. The obtained data were analyzed using both descriptive (percentages, mean and standard deviation) and inferential (Chi-square and correlation analysis) statistics. The findings of the study revealed that promotional activities (sales promotion, advertising, and personal selling) significantly affected the sales 
performance of insurance companies, while public relations did not have any significant effect on sales performance. Therefore, the study recommended that insurance companies should engage in maximum utilization of the entire promotion mix to enhance sales growth. Nyarko (2015) conducted a study on "Promoting life insurance products via personal selling: The case of a leading insurer in Ghana". The purpose of this study was to establish the contribution of personal selling to the promotion of life insurance products in Ghana. Primary data were collected from 100 clients of a leading insurer in the city of Housing a questionnaire. Simple frequency distribution tables were used to analyze the data collected. The findings of the study revealed that personal selling is an essential tool in prospecting, informing, educating, and persuading life insurance clients. Therefore, the study recommended that insurers must recruit and train more salespersons to intensify these activities. Also, insurance companies should consider apportioning a good percentage of their promotion budget to developing salespersons.

Furthermore, Olumoko, Abass, and Dansu (2017) conducted a study on "The role of personal selling in enhancing client satisfaction in the Nigerian insurance market". The purpose of the study was to examine how personal selling could be used to enhance clients' satisfaction in the Nigerian insurance market. Survey questionnaires were used to obtain primary data from 110 clients of selected insurance firms in Nigeria. Data analysis procedures were done using descriptive and inferential statistical instruments while an independent T-test was used to test the hypotheses. Consequently, the findings revealed that a personal selling strategy is the most beneficial marketing communication tool that should be embraced by Nigerian firms because of its great potential to enhance clients' satisfaction. Therefore, the study recommended that personal selling should be considered by all insurance service providers as the ideal method of marketing communication because no other promotional tool allows personalized and modifiable buyer-seller communication which is necessary for the sales of insurance services. Finally, Owolabi and Magbagbeola (2017) conducted a study on the "Impact of advertising on the sales of insurance products in Sub-Saharan Africa". The purpose of the study was to determine the impact of and relationship between advertising and the sales of insurance products in Nigeria. Structured questionnaires were used to collect primary data from 100 personnel of insurance companies in Osun State, Nigeria. Correlation analysis and descriptive statistics (proportions and frequency tables) were used to analyze the data collected. As a consequence, it was revealed a positive impact and correlation between advertising and sales of insurance products in Nigeria. Hence, the study recommended that advertising should be a regular programme for insurance companies due to its continuous impact on consumers especially in the area of awareness creation.

\section{Methodology}

The study adopted a cross-sectional survey research design. Primary data used in the study were collected from insurance companies' personnel (such as branch managers, unit managers, and marketers) on a one-time basis using a structured questionnaire. The target population of the study included 192 employees of four (4) insurance companies in Calabar, Nigeria. Given that the population was small and manageable, all 192 employees of the selected insurance companies were adopted as a sample for the study. This action was informed by the prescription of Kuteesa (2020), which states that where population size is relatively small (300 and below), it is advisable for the researcher to study the entire population as a sample. The instrument of data collection was a 5-point Likert scale questionnaire adapted from the scholarly studies of Enitilo, Ajayi, and Famuagun (2017); and Idris et al. (2018). The instrument was made up of two sections; namely: Section A (which collected respondents' demographic data such as age, gender, marital status, and educational qualifications), and Section B (which contained statements drawn from the study variables: advertising, personal selling, public relations, direct marketing and marketing of insurance services). The opinions of respondents were measured on 5-Point Likert Scales of Strongly Agree ( $S A=5$ points), Agree $(A=4$ points), Undecided $(\mathrm{U}=3$ points), Disagree ( $\mathrm{D}=2$ points), and Strongly Disagree ( $S D=1$ points). Statements $1-3$ measured advertising; statements 4 - 6 measured personal selling; statements 7 - 9 measured public relations; statements $10-12$ measured direct marketing; while statements 13 - 15 measured marketing of insurance services. Subsequently, the instrument was confirmed for validity through content validity and reliability through the internal consistency approach using Cronbach's alpha coefficients. From the reliability test done on data obtained during a pilot survey of insurance companies' personnel, the Cronbach's alpha coefficients of the five (5) constructs are as follows: Advertising $=0.781$, Personal Selling $=0.790$, Public Relations $=0.735$, Direct Marketing $=0.777$ and Marketing of Insurance Services $=0.801$. Since the Cronbach's alpha coefficients of all measures of the questionnaire exceeded 0.7, the instrument was considered reliable and adopted for field administration to respondents. The data obtained, therefore, were analyzed using descriptive statistics, while the hypotheses developed for the study were tested using multiple linear regression in the Statistical Package for the Social Sciences (SPSS 23).

\section{Results and Discussion \\ 4.1. Test of Hypotheses}

TABLE 1

Model summary of the effect of promotional mix on the marketing of insurance services

\begin{tabular}{|l|l|l|l|l|}
\hline Model & R & R Square & Adjusted R Square & Std. Error of the Estimate \\
\hline
\end{tabular}




\begin{tabular}{|l|l|l|l|l|}
\hline 1 & $.323^{\mathrm{a}}$ & .105 & .084 & .62553 \\
\hline
\end{tabular}

a. Predictors: (Constant), Advertising, Personal selling, Public relations, Direct marketing

TABLE 2

ANOVA of the effect of promotional mix on the marketing of insurance services

\begin{tabular}{|ll|l|l|l|l|l|}
\hline Model & Sum of Squares & Df & Mean Square & F & Sig. \\
\hline 1 & Regression & 8.087 & 4 & 2.022 & 5.167 & $.001^{\mathrm{b}}$ \\
& Residual & 69.257 & 177 & .391 & & \\
& Total & 77.344 & 181 & & & \\
\hline
\end{tabular}

a. Dependent Variable: Marketing of insurance services

b. Predictors: (Constant), Advertising, Personal selling, Public relations, Direct marketing

TABLE 3

Coefficients of the effect of promotional mix on the marketing of insurance services

\begin{tabular}{|c|c|c|c|c|c|c|}
\hline \multirow{2}{*}{\multicolumn{2}{|c|}{ Model }} & \multicolumn{2}{|c|}{ Unstandardized Coefficients } & \multirow{2}{*}{$\begin{array}{l}\text { Standardized } \\
\text { Coefficients } \\
\text { Beta } \\
\end{array}$} & \multirow[b]{2}{*}{$\mathrm{t}$} & \multirow[b]{2}{*}{ Sig. } \\
\hline & & B & Std. Error & & & \\
\hline \multirow[t]{5}{*}{1} & (Constant) & 2.405 & .653 & & 3.683 & .000 \\
\hline & Advertising & .175 & .074 & .185 & 2.367 & .019 \\
\hline & Personal selling & .257 & .098 & .202 & 2.634 & .009 \\
\hline & Public relations & -.182 & .082 & -.009 & -2.232 & .127 \\
\hline & Direct marketing & -.007 & .061 & .169 & 1.108 & .004 \\
\hline
\end{tabular}

a. Dependent Variable: Marketing of insurance services

\subsubsection{Interpretation of Result}

Tables 1, 2, and 3 present the multiple linear regression results of the effect of the promotional mix on the marketing of insurance services. The model summary presented in Table 1 shows that the correlation between the independent variables (promotional mix) and the dependent variable (marketing of insurance services) is 32.2 percent (as can be seen in the R column), thereby indicating that there is a weak degree of correlation between the study variables. The R2 (coefficient of determination) value of 0.105 , signifies that up to 10.5 percent of the variation in the dependent variable (marketing of insurance services) can be explained by the independent variables (promotional mix). Hence, a unit change in promotional mix strategies of insurance companies will affect the marketing of insurance services by up to 10.5 percent when other factors are held constant. The $\mathrm{F}$-test $(5.167, \mathrm{P}<0.05)$ statistic in Table 2 signifies that the overall prediction of the dependent variable by the independent variable is statistically significant; therefore, implying that promotional mix has a significant effect on the marketing of insurance services. Table 3 (the coefficients table) provides information on the capability of each promotional mix dimension to explain or predict the marketing of insurance services.

As can be seen in Table 3, three of the four promotional mix variables tested (advertising, personal selling, and direct marketing) were found to significantly predict or explain the marketing of insurance services, because their $p$-values [advertising $(p$-value $=$ 0.019), personal selling ( $p$-value $=0.009)$ ] and direct marketing ( $p$-value $=0.004)$ ] are less than the error margin of 0.05 , with positive t-test values indicating that the relationship between these variables (advertising, personal selling, and direct marketing) and the marketing of insurance services, is a direct and positive one. However, one promotional mix dimension tested (public relations) did not significantly predict or explain the marketing of insurance services because its $p$-value [public relations ( $p$-value $=0.127$ ) ] is greater than the error margin of 0.05. Furthermore, the standardized beta coefficient column in Table 3 shows the individual contributions of each promotional mix variable to the model. As can be seen in the column, the highest contributing promotional mix variable to the model is personal selling, with a beta coefficient of 0.202 (20.2 percent). The second-highest contributing promotional mix variable to the model is advertising, with a beta coefficient of 0.185 (18.5 percent). Also, the thirdhighest contributing promotional mix variable to the model is direct marketing, with a beta coefficient of 0.169 (16.9 percent). Public relations had a negative and non-significant contribution to the model, with a beta coefficient of -0.009 ( -0.9 percent). Finally, since the $p$-values of advertising $(p$-value $=0.019)$, personal selling ( $p$-value $=0.009)$, and direct marketing $(p$-value $=$ 0.004 ) are less than the error margin of 0.05 , we reject null hypotheses one, two, and four and accept alternative hypotheses one, two and four, leading to the conclusion that advertising, personal selling, and direct marketing had significant positive effects on the marketing of insurance services. Conversely, null hypothesis three was accepted because the $p$-value of public relations ( $p$ - 
value $=0.127$ ) is greater than the error margin of 0.05 . Therefore, the results show that public relations had no significant effect on the marketing of insurance services.

\subsection{Discussion of Findings}

The first hypothesis test revealed that advertising has a significant effect on the marketing of insurance services. This finding is supported by the study of Aduloju, Odugbesan, and Oke (2018), which revealed that advertising (radio advertising, television advertising, social media advertising, and billboard advertising) had a significant effect on the sales volume and public image of insurance companies in Lagos. The finding is also backed by the study of Enitilo, Ajayi, and Famuagun (2017), which revealed that media advertising had a significant influence on customer patronage of insurance companies in Ado-Ekiti. The implication of this finding is that advertising has been statistically proven to significantly improve the marketing of consumer products and services across industries and geographical locations.

The second hypothesis test revealed that personal selling has a significant effect on the marketing of insurance services. This finding is reinforced by the study of Idris et. al. (2018), which revealed that personal selling significantly improved the marketing of insurance services in Nigeria. The finding also corresponds with the study of Kinoti, Nkari, and Kathuni (2019), which found that personal selling significantly affected the sales performance of insurance companies. This finding implies that irrespective of geographical location or industry of application, the use of the personal selling strategy has the universal capacity to significantly enhance the marketing of consumer goods and services.

The test of hypothesis three revealed that public relations have no significant effect on the marketing of insurance services. This finding is contrary to the study of Idris et al. (2018), which found that public relations significantly improved the marketing of insurance services in Nigeria. However, the finding aligns with the study of Kinoti, Nkari, and Kathuni (2019), which also affirms that public relations did not have any significant effect on the sales performance of insurance companies. This finding implies that although personal selling has been proven to be effective in enhancing the marketing of products and services in various sectors, its capacity to enhance the marketing of insurance products has been statistically disproved, hence indicating that the efficacy of the public relations strategy at improving the marketing of insurance services is limited.

Finally, the test of hypothesis four revealed that direct marketing has a significant effect on the marketing of insurance services. This finding corresponds with the studies of Enitilo, Ajayi, and Famuagun (2017) as well as Idris et al. (2018), which revealed that direct marketing had a significant influence on customer patronage of insurance services. The implication of this finding is that like advertising and personal selling, the capacity of direct marketing to significantly enhance the marketing of insurance services across the world has been statistically established.

\section{Conclusion}

Informed by the application of promotional mix strategies by insurance companies around the world, this study was geared towards assessing the extent to which promotional mix strategies (advertising, personal selling, public relations, and direct marketing) influenced the marketing of insurance services. To that end, the study used a 5-point Likert scale questionnaire to obtain primary data from employees of insurance companies for analysis. The hypotheses developed for the study were statistically tested using the multiple linear regression method. Consequently, the findings of the study revealed that advertising, personal selling, and direct marketing had significant positive effects on the marketing of insurance services, while public relations had a negative and non-significant effect on the marketing of insurance services. This implies that the marketing of insurance services can be significantly enhanced through the implementation of effective promotional mix strategies such as advertising, personal selling, and direct marketing. This is because, in the insurance industry of most developing countries, insurance service is hugely an unsought service characterized by negative consumer attitudes and low demand. Promotional mix strategies could therefore play pivotal roles in informing, persuading, and convincing consumers of the need to patronize insurance services, thereby substantially improving the marketing performance of insurance companies. The study was constrained to four (4) indicators of the promotional mix, namely: advertising, personal selling, public relations, and direct marketing; hence it could not take into account the potential effects of other promotional mix elements such as word-of-mouth, sales promotion and publicity on the marketing of insurance services. There is therefore the need for holistic studies that explore the individual contributions of other promotional mix elements such as word-of-mouth, sales promotion, and publicity on the marketing of insurance services. Similarly, the study examined the effect of promotional mix from the perspective of employees of insurance companies with no reference to the insurance customer's point of view; hence it could not demonstrate how insurance consumers respond to the promotional mix of insurance companies and the potential effect of insurance companies' promotional mix on customers' patronage. Therefore, future researchers should pay attention to the insurance customer's perspective by exploring the effect of the promotional mix on consumer buying behavior towards insurance services.

Funding: This research benefitted from no external funding. 
Acknowledgments: The researchers sincerely acknowledge the authors whose scholarly research articles and literature materials were cited in this study, thereby enabling its successful completion. All external reviewers who were meticulous in reviewing the draft copy of the work and making valuable contributions to it are hereby formally acknowledged. Finally, we acknowledge the insurance companies' personnel who responded to the research questionnaire despite their busy schedules.

Conflicts of Interest: The authors hereby declare no conflict of interest.

\section{References}

[1] Abeid, Y. (2019). Promotion strategy prudence and the sales effect of advertising: The case of Zanzibar Insurance Corporation [A doctoral dissertation, Mzumbe University]

[2] Aduloju, K., Odugbesan, A. O. \& Oke, S. A. (2018). The effects of advertising media on sales of insurance products: A developing-country case. The Journal of Risk Finance, 10(3), 210-227

[3] Agusto \& Co. (2019). 2020 Insurance industry report. https://www.agustoresearch.com/product/2020-insurance-industry-report/

[4] Anyadighibe, J. A., Awara, N. F. \& Esu, B. B. (2014). The impact of personal selling on the productivity of selected banks in Calabar Metropolis. International Journal of Development and Sustainability, 3(8), 1697-1708.

[5] Atlas Magazine (2019). The insurance industry in Africa: Ranking 2018 of countries by turnover. https://www.atlasmag.net/en/article/insurance-market-in-africa-ranking-2018-of-countries-by-turnover

[6] Benson, E. A. (2020). Here's what will happen to Nigeria's insurance sector in the short to medium term. https://nairametrics.com/2020/06/30/heres-what-will-happen-to-nigerias-insurance-sector-in-the-short-to-medium-term/

[7] Dominic, B. \& Tancredi, F. (2012). Effect of marketing communication on customer patronage of exotic cosmetic products in Maine, United States. Journal of Business and Management Invention, 2(3), 31-38.

[8] Ebitu, E. T. (2012). Marketing communications: An integrated approach (1st Ed.). University of Calabar Press.

[9] Enitilo, O., Ajayi, I. E. \& Famuagun, F. Y. (2017). Influence of promotional activities on consumers' patronage of insurance business in Ado Ekiti Metropolis, Nigeria. International Journal of Economics, Commerce and Management, 5(1), 414-436

[10] Ericsson, R. (2020). What is a promotion mix? - Tips and examples. https://sendpulse.ng/support/glossary/promotion-mix

[11] Fitchner, W. (2016). What is marketing communication (MarCom)? https://learn.marsdd.com/mars-library/what-is-marketingcommunication-marcom/

[12] Gera, R., Mittal, S., Batra, D. K. \& Prasad, B. (2017). Evaluating the effects of service quality, customer satisfaction, and service value on behavioral intentions with life insurance customers in India. International Journal of Service Science, Management, Engineering, and Technology, 8(3), 1-20.

[13] Gollust, S. E., Wilcock, A., Fowler, E. F., Barry, C. L., Niederdeppe, J., Baum, L. \& Karaca-Mandic, P. (2018). TV advertising volumes were associated with insurance marketplace shopping and enrollment in 2014. Health Affairs, 37(6), 956-963

[14] Idris, A. (2020). Inside the wave of disruption sweeping Nigeria's sluggish insurance industry. https://techcabal.com/2020/06/10/nigerianinsurance-fintech-disruption/

[15] Idris, A. A., Asokere, A. S., Ajemunigbohun, S. S., Oreshile, A. S. \& Olutade, E. O. (2018). An empirical study of the efficacy of marketing communication mix elements in selected insurance companies in Nigeria. Australian Journal of Business and Management Research, 2(5), 818

[16] Isimoya, O. A. \& Olaniyan, M. S. (2020). Impact of relationship marketing dimensions on word of mouth communication in the insurance industry in Nigeria. Acta Universitatis Danubius. Fconomica, 16(3), 67-79

[17] Kinoti, P. N., Nkari, I. M. \& Kathuni, L. K. (2019). Promotional strategies and sales performance of insurance companies. International Journal of Business and Social Science, 10(8), 104-109

[18] Kuteesa, H. (2020). RE: What conditions justify studying the entire population instead of selecting a sample? https://www.researchgate.net/post/What-conditions-justify-studying-the-entire-population-instead-of-selecting-a-sample

[19] Logan, C. \& Edwards, P. (2004). Towards a rapid response model of marketing communication: The integrated marketing communication approach. European Journal of Marketing Management, 63(12), 113-116.

[20] Mathur, T. (2020). Marketing health insurance products: Sources and consequences of customers' confusion. International Journal of Healthcare Management, 1-11.

[21] Maxwell, J. (2017). Promotion mix. https://businessjargons.com/promotion-mix.html

[22] Minta, Y. (2018). The link between satisfaction and customer loyalty in the insurance industry: Moderating effect of trust and commitment. Journal of Marketing Management, 6(2), 25-33.

[23] Novi, N. H. (2020). Investigating the relationship between promotion mix and marketing performance criteria from the viewpoint of insurance company employees. Archives of Pharmacy Practice, (4)1, 64-66.

[24] Nyarko, I. K. (2015). Promoting life insurance products via personal selling: The case of a leading insurer in Ghana. British Journal of Economics, Management \& Trade, 7(3), 175-182

[25] Okpulor, C. (2017). Public relations strategies for enhancing the image of insurance companies in Imo State (A doctoral dissertation, University of Nigeria, Enugu).

[26] Olumoko, T. A., Abass, O. \& Dansu, S. (2017). The role of personal selling in enhancing client satisfaction in the Nigerian insurance market. Journal of Emerging Trends in Economics and Management Sciences, 3(2), 147-152

[27] Owolabi, A. O. \& Magbagbeola, J. A. (2017). The impact of advertising on the sales of insurance products in Sub-Saharan Africa. International Journal of Current Research, 3(6), 251-255

[28] Prymostka, O. (2018). Life insurance companies' marketing strategy in the digital world. Insurance Markets and Companies, 9, 66-73.

[29] Ratnakaram, S., Chakravaram, V., Vihari, N. S. \& Rao, G. V. (2020). Emerging Trends in the Marketing of Financially Engineered Insurance Products. In ICT Systems and Sustainability (pp. 675-684). Springer: Singapore. 
[30] Shao, T., Shinzo, E., \& Kyutomo, P. (2019). Evaluation of the impact of promotional mix on the marketing performance of deposit money banks in Japan. Asian Journal of Information, Communication, and Technology in Business, 20(8), 5-16

[31] Sydney, G. (2016). Importance of marketing communication. https://www.marketing91.com/importance-of-marketing-communication/

[32] Wade, G., Williams, J. \& Bradley, P. (2019). Relationship between marketing promotional mix and customer loyalty in the Norwegian telecommunications industry. International Journal of Management Research and Business Strategy, 2(2), 12-28

[33] Wayne, P., Purcell, D. \& Robert, K. (2016). Impact of promotional mix on organizational performance: Evidence from Tehran. European Journal of Business and Management, 3(3), 67-89 